\title{
THE SOCIETAL CRISIS AND THE HUMAN DIGNITY: EPISTEMOLOGICAL VIEW
}

\begin{abstract}
The paper aims at emphasising the significances of the concept of dignity through the lens of the relational character of this concept. Even though it appeared in modernity as substantive/essence, as an autonomous state that might be attached to man - and it was developed in the frame of methodological individualism -, dignity is a construct depending on the historical and social relations, thus the culture and values dominant in a certain time. And, because the consideration of the others is assumed by the individual who internalises the intertwining and force of values in the way he seems to not detach his own being from dignity, the paper demonstrates that, although there is an ontological basis of dignity - the human conatus - the concept of dignity is incomprehensible without connect it to, or more, without integrating it within the social complex.

First of all, the individual translation of the human conatus in the concept of dignity supposes the social character of man. The instruments of the individual, necessary for his survival, are social. The language through which he expresses his self-consciousness as his own dignity is social. The nuances his self-consciousness transposes as feelings and their expressions are borrowed from the culture known by the individual.

But leaving this alone, and considering as a beginning of the analysis only the individual's feeling of dignity as transposition of his/her will to live, this feeling is vague, ineffable and evanescent if it would not have the positive or negative reactions of society towards it. Indeed, society is the ultimate criterion of the individual consciousness of dignity, because it accredits this individual feeling. If, by absurd, there was no society - or the individual would live in an individual niche and would not know anything about society (but, for the sake of our philosophical experiment, he could express through meaningful words his feelings) - the individual would not be sure that he has a constitutive dignity and he deserves dignity. Only the others authorise this feeling, whether they endorse it or not, having the function of a thermometer measuring the individual belief.

Methodological individualism is contradictory concerning the concept of dignity: on the one hand, it lauds to sky this concept (in its essentialist variant) as related to the individual, and on the other hand, it neglects the consequences of social relations over the real state of dignity of all the human beings.

Finally, the paper links this relational standpoint to both the surpassing of the abstract individual and the clash of universalistic and particularistic values.
\end{abstract}

Keywords: dignity, individual, essentialist and relational views, oikeiosis, joy of life, universalism, particularistic view, intellectuals.

1. The modern origin of the present meaning of the concept of dignit

As many - if not all - the concepts concerning the human society, dignity is not the reflection of a fix and clear datum of reality, but a construct, thus inherently historical, social and subjective. The constructivist approach assumed here sends to the historical localization of the creation of the concept. This localization pertains to the birth of modernity. And the above word - "subjective" - does not mean that every human person would have an untrans- 
latable image about the world, hence the impossibility of common criteria and values resulting, but only that the world as it appears to the human beings is that which is seen/known by them. The world is certainly objective, but its meanings, features and colours are depending on the natural and artificial instruments man approaches them.

The constructivist, historical perspective allows fathoming that dignity is a modern term, since it is related to all humans, as a real, but feasible quality of them, beyond every discussion related to the abstract model of man. The rise of modernity with its new approach of the free/emancipated individual (Burkhardt 1978) and open relationships submitted to the public opinion (publicity/transparency as rights (Kant 1996)) has brought the confidence in the novel trend of a normalcy of transformation and social transparency. In this confidence, the praise of the individual has contained the expectation that the abstract character of man will be surpassed and that everyone and all will acquire their dignity. As we know, Giovanni Pico della Mirandola was the modern theorist of dignity in the European culture. He gave the reasons of the concentrated characteristic of man he focused on: every man would be dignified or worthy in principle, because every man is capable to shape himself according to his own will. This feature - to be able to shape oneself had in the upstream that man: 1) is a free being because he has the free will belonging only to him from the whole class of animals; thus, the social fact of freedom was, in this theory, the result of the marvellous natural hazard of the human free will; 2) that man has reason which is, as later on Descartes pointed out, "the most evenly distributed thing in the world" (Descartes 2000: 5; 12); 3) man judges his decisions, he chooses; 4) in order not to fall into decay, but to elevate.

Though Pico has based his theory on God's decision to have created such a special being - it is God which "bestowed seeds pregnant with all possibilities, the germs of every form of life" (Pico 1996: 8) -, once He decided the form of His creation (as followed from Pico's reasoning), He let this one free, namely with free will: just as later on Erasmus has specified in a work reflecting the most progressive anti-Protestant argument of the Catholic Church (Erasmus 1524); this argument was that of the human free will leading to humans' choice between good and evil; this free will was the immediate (efficient, in Aristotle's terms) cause of human facts, and not God - who was only the ultimate cause -; He could predict the evolution, the fate of humans, but never interfered in men's choices, who were the only responsible for the consequences of their decisions. In the language of Renaissance, it was necessary to demonstrate man's free will as God's decision; God would have been the omnipotent Pater counselling His creature; "We have made you a creature..." (Pico 1996: 7). But, besides this diplomatic moment of ultimate origin of man's genuine power, in the modern thinking no discussion about man's deeds did not necessitate this "hypothesis" (as even more later on it is said Laplace would have circumscribed his cosmogony theory).

If so, the analysis of man emphasises the exceptional character of man: he is like God, since he is "the free and proud shaper of your own being", fashioning himself "in the form you may prefer". Man is not a simple animated creature following the path of infinite repetitions of its instincts, but a being that has in its "power to descend to the lower, brutish forms of life" or "to rise again to the superior orders whose life is divine" (Pico 1996: 8).

Just this capacity - and the human reason makes man a creature "of heaven and not of earth" and this means that man is a "higher divinity, clothed in human flesh" (Pico 1996: 11) is which gives man dignity: to every man, and not as until this spring of modernity, only to God and some humans.

In Pico, dignity is a divine feature, and now it becomes every man's dignity: the most specific quality of man. 
As a general and universal quality - signalling the modern development of universalistic values, beyond every particular manifestation of people within their cultures -, dignity has been developed as an essence, or substantive concept designing an autonomous state towards which people strive to enter within. An autonomous desirable state: that may be described as an "objective" thing with somehow neutral characteristics which may be acquired exclusively through the individual effort. Here is the essentialist standpoint: as if the individual effort would lead to dignity without the endorsement of the others.

This is the reason of the lack of interest of the modern philosophers: who considered dignity either a supposed, implied general state, or an arid quality, instead of which it was more useful to study the mechanisms supporting dignity. Between these mechanisms the most important were those of the human reason/consciousness and not, or in a far lesser measure, those of the social relationships. The methodological individualism was, thus, linked to specific neglects of the philosophical research.

This situation has corresponded to the historical division between the physical and intellectual work: where the bearers of the latter were not too sensitive towards the bearers of the former, and where the preoccupations towards the problems of the human being were satisfied through the abstract individual. But, obviously, this state of things was too the result of the general level of understanding, culture and civilization.

2. But dignity is a relation, the result of inter-human relationships

Actually, just etymology shows that the essentialist standpoint and approach of the concept of dignity is a weak one. Dignity is neither an inherent quality of man, nor an a priori of all men, nor again an objective entity (like Plato's ideas). People have considered themselves - or, better, one or another member of the communities they lived within - as worthy of respect according to the concrete deeds and behaviour of these members and, more, according to the ideological representations and values dominant in their communities and assumed by the bearers of this attitude. These representations and values were the criteria of people's assessment and 'measurement" of their and others' behaviour.

Then respect is given by the others and, because this respect of the others is very pleasant, being a necessary element of the humans' need have esteem (see A. Maslow), it is highly desired. But what is respect? It is the estimation that an individual has realised the tasks he ought to fulfil at the highest level possible, and that he deserves public recognition for this: public recognition of the good or adequate/commensurate facts and behaviours. The test of practice is which shows that an individual deserves or not respect. At the same time, practice is the ground emphasising people's representations, prejudices and clichés forged within the power relations/relations of forces which establish the dominant values.

The human civilisation structured and framed by the power relations has transposed into the $m a-$ terial exteriorisation of the intangible human respect. Respect became dignity, and dignity was the attribute of those who managed the social relations: the rulers, the powerful. Dignity became a characteristic of these ones: the more so as it was manifested in forms transformed into habits. The essentialist standpoint about dignity originates in this social/political mediation of the technically/ontologically proper or suitable or correct qualities of facts and behaviours.

The Sanskrit etymology illustrates the relational standpoint. On the one hand, one name of respect/attention/consideration - pratikSA - comes from the verb Aprathayati, to spread, to extend (the others' opinion about). On the other hand, another name of respect is tejasvin (coming from tejas, authority) meaning: inspiring respect, noble, powerful, dignified. 
Things are, certainly, more complicated. The attitude of people towards each other was separated from this relational origin and objectified. For example, another name of respect, Adara, came from the name of regard (as both looking and considering) and, with a slight $h$, (Adhara) was also base, foundation, grounds. Not the origins of these words are important here, but the logic they articulated. For example, the same origin in the verb Aprathayati has led to the adjective mahApratApa, very dignified.

But the Latin, closer to us, shows the same logic. Dignātĭo -ōnis - esteem, deference, and respect - has led to dignĭtās - ātis, title, merit, eminence, dignity. Actually, dignity was not necessarily the exterior sign - given by the others - of the correct, if not exceptional behaviour of a person according to the results of his deeds, but of his superior social status. The respect of the others is shown through their psychic attitude towards the person. The bow of reverence is not necessary: a simple smile and warm tone of the voice is sufficient. If there are excessive signs of obeisance, as well as gifts and privileges, they follow from the social relations of domination-submission.

Therefore, dignity is the particularity of man historically, missing from the existence of the majority of humankind - resulted from the social terms. These ones translate, transpose, but also create activities, goals, values necessary as means of the humans' preservation.

Actually, if by absurd the human individuals would born instantaneously following the will of a god and would live absolutely alone, if they would not need any other human fellow and nor would they come across other people, they would not know the feeling to having dignity and to striving for dignity. Without society, there would not be any idea of dignity. The desire of dignity shows the state of society, of social relations, of its tradition and culture and of its capacity to integrate the individual aspirations of creation, of realisation of the self.
Letting aside history, this emphasis on the relational character of the concept of dignity is the most important in our everyday life. No, dignity is not an inherent quality of man, but the estimation of the others during the social relations. The positive estimation made by every human being towards himself is very important for him; but it is not sufficient to think to myself as a dignified person: it is absolutely necessary the others do the same, and this social consideration must transpose not only into a respectful tone and cared language, but compulsorily into dignified conditions of living. These means: conditions so as to can develop my creativity, my divine uniqueness.

And, for I grasped what the respect of others means and I want to be respected, and for this desire is or brings my consciousness of my uniqueness - i.e. this desire and consciousness is dignity -, I understand that I have to behave in such a manner as to be respected, as to my dignity be respected. Consequently, I am not a lazybones and I give to the others as much as I can, in order to receive in exchange their respect and the social conditions necessary to develop my possibilities to create. Therefore, the consciousness of my dignity does not enclose me in the circle of my solipsism and does not favour an asymmetrical relation Me-society but, first of all, the feeling of belonging to society and then the feeling of reciprocal relation of supply and demand: I require my dignity and my dignity to be recognised, and I offer my full will to create and to recognise the dignity of the others.

\section{Ontological foundation of the human dignity}

In fact, the feeling of being dignified or having dignity, though it is shaped/ culturally translated by society, nevertheless has a profound impulse in the mind-body unity of the human being. If we ask and we must do this - why man (but this means: each man and all of them) must have dignity, or what the presumption of dignity is based on, we un- 
derstand that we plunge into the level of ontological foundation of the existence of the human being.

How can we describe man so as to give reasons to his endeavour, his effort, his aspirations and expectations? Are all of these only random occurrences within a mad dance of indeterminism? (Or: of a grey determinism of routines passing in the same random manner?) Or: only some aspirations and claims would be legitimate, and other - like dignity - would be suspect?

\section{A. Conatus}

Actually, the desire of dignity has its ground in the human conatus. As we know, the conative ${ }^{1}$ force or the will to persist was suggested by Plato's nephew Speusippus (408 - 339/8 B.C.) in his Definitions (Diogenes Laërtius 1972: Book IV, 5) which were considered by some ones as Plato's work; but it is an apocryphal Plato. Anyhow, in this book, the power of the soul to move by itself is the cause of the vital movement of the living beings ${ }^{2}$. Later on, by meditating on the reason of the vital movement, the Stoics said that this reason is self-preservation: "An animal's first impulse, say the Stoics, is to selfpreservation, because nature from the outset endears it to itself, as Chrysippus ${ }^{3}$ affirms in the first book of his work On Ends: his words are, "The dear-

\footnotetext{
${ }^{1}$ In Latin, cōnātŭs - ūs is effort, attempt, trial, inclination; and cōnor - àri, àtus sum - to try, to dare, to compel, to prepare.

2 (Platon MDCCCXL: 195, 197): "L'âme est ce qui se meut soi-même et la cause du mouvement vital des êtres vivants. Une force est ce qui agit par soi-même...le sentiment de l'ordre est la soumission volontaire à ce qu'on reconnaît pour le bien, le calme au milieu des mouvements du corps ". (The soul is that which moves itself and is the cause of the vital movement of living beings. A force is that which acts trough itself...the sentiment of order is the voluntary submission to what one recognises as the good, the calm in the midst of the movements of the body).

${ }^{3}$ 282-206 B.C.
}

est thing to every animal is its own constitution and its consciousness thereof" ; for it was not likely that nature should estrange the living thing from itself or that she should leave the creature she has made without either estrangement from or affection for its own constitution. We are forced then to conclude that nature in constituting the animal made it near and dear to itself; for so it comes to repel all that is injurious and give free access to all that is serviceable or akin to it" (Diogenes Laërtius 1972: Book VII, Zeno, 85).

Then, this will to self-preservation was either understood and implicated - i.e. something noninteresting, as dignity was - or a too difficult problem in front of the social reality. How could the philosophers write about self-preservation when the value of the human person was so insignificant in the whirlpools of wars and despotic decisions? However, from the standpoint of universalism, St. Augustine of Hippo has repeated the Stoics' argument (it is nature that impulses man to love himself and to have an instinctive aversion towards death, because he wants to keep the union of the body and soul (Augustin 1855: 19). Thomas Aquinas too was interested to justify the universalism of the ideology of the time: it was absolutely necessary to point out man as the privileged creature of God. The superiority of the human being was based on its consciousness of the natural conatus ${ }^{4}$.

\footnotetext{
${ }^{4}$ (Thomas Aquinas 1265-1274, Secunda Secundæ Partis, Question 64. Murder, Article 5. Whether it is lawful to kill oneself? Article 1, Reply to Objection 1, http://www.newadvent.org/summa/3064.htm): “According to the Divine ordinance the life of animals and plants is preserved not for themselves but for man. Hence, as Augustine says (De Civ. Dei i, 20), "by a most

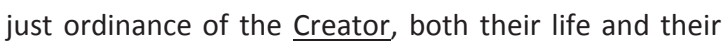
death are subject to our use".

And op. cit., Article 5, http://www.newadvent.org/ summa/3064.htm\#article5: "everything naturally loves itself, the result being that everything naturally keeps itself in being, and resists corruptions so far as it can".
} 
However, universalism was not the fashionable feature of Christianity: it was promoted, somehow outside the current, only by idealist theorists and common people opposing the socially induced suffering. But the birth of modernity has given hope that the leadership of society would promote democracy and respect of the human being. It is not without significance that Spinoza with his conception of radical democracy has remembered to thinkers and decision-makers that "Everything, in so far as it is in itself, endeavours to persist in its own being" (Spinoza 2002: 283). Everything "is opposed to all that could take away its existence. Therefore, in so far as it can, and in so far as it is in itself, it endeavours to persist in its own being" (ibid., Proof). While Leibniz, in the same spirit of rationalism ${ }^{5}$ and implicit democratic respect of the human being, aimed too at demonstrating the foundation of conatus $^{6}$.

\section{B. Oikeiosis and the joy of life}

The problem was (and is) that it is not enough to show that every man wants to persist. It is equally important to emphasise that he wants to persist as a human being, in a human manner.

\footnotetext{
5 (Leibniz 1921: 154): "there are people who think that it would be of bel esprit to rant against reason".

${ }^{6}$ (Leibniz 1694/1890: 69-70): "active force includes a sort of act or $\varepsilon v \tau \varepsilon \lambda \varepsilon \dot{\chi} \varepsilon \varepsilon v_{0}$, which is midway between the faculty of acting and the action itself and involves an effort, and thus of itself passes into operation; not does it need aid other than the removal of impediments", this force being "energy or virtue, called by the Germans kraft, and by the French la force".
}

See also (Leibniz 1714/1890: 219-220) where he insisted: "11. The natural changes of the monads proceed from an internal principle" and "15. The action of the internal principle which causes the change or the passage from... ("a transient state" to another, a transient state of reaction/conatus". At the level of living bodies, it is more understandable: as instinct of selfpreservation.
The old concept of the Stoics, oikeiosis, helps us. It meant in fact that, normally, every man feels "at home" (oikos) in his being. By using the related Greek words, Wayne M.Martin (2006) has indicated the plural meanings of the term: as "self-consciousness, self-awareness or sentiment of self", as familiarization, affinity, as conatus. But I think that the origin of the word allows us to mention not a "simple" self-awareness, but also the feeling of good related to the personal conatus. The folk saying refers to the fact that, normally, man "feels comfortable in his skin". If this does not happen, it means that the person is ill in a way or another and feels that his body/even his mind does no longer correspond to his soul's enthusiasm. He does not "feel comfortable in his skin" and wants to transform it somehow just in order to accord it with his élan, his conatus.

Or, the individual, as healthy he is and physically having no troubles, is restless and worried, indignant, feeling his helplessness to follow his will to live / or rather, his will of life to follow from his helplessness. It is not his body that brakes him, and nor even his mind imagines painful situations so as he feels as in a nightmare. It is not about imagination, it is real life. He feels his possibility, his availability to create something marvellous and to participate to the effort of society to construct: since life is always construction. But he cannot actualise his possibility: the path of his life was shaped once and for all, and he cannot - as formally free as he is - escape.

In this moment, his conatus is hit, sometimes until he questions his raison d'être (Camus 1942). And therefore, he can no longer feel comfortable in his life. It is the joy of life that misses to him.

To feel at home in our life, to have reasons for our striving for keeping it needs not only our conatus, but also our joy of life. And if philosophers were in a way or another preoccupied with the first, they were not concerned of the joy of life. But this is a big shame, because the joy of life is an ontological concept, as conatus is. 
Spinoza spoke about it: because man has the consciousness of his effort to persist, he has feelings related to this effort. And the most important feeling is the joy (hilaritas) because it is felt by the integral human being, by both mind and body, while sadness and the desire relate to the most affected part of man (Spinoza 2002: 285). As a result, the good is "every kind of pleasure, and all that conduces thereto, especially that which satisfies our longings, whatsoever they may be" (ibid: 298). And "when the mind regards itself and its own power of activity, it feels pleasure" (ibid: 305). Does it not follow from this that man must do everything in order to always experience joy of life?

And, because Spinoza has utilised the word "pleasure", it should be noticed that joy of life is not pleasure. According to Henri Bergson, the sign of man's consciousness and élan vital is the "joy of life": it is not "pleasure" since this one is only the means nature gave to man in order to conserve his life, but the "announcement" that life has succeeded and that "there is creation" (Bergson 1919: 18-25).

If there is no joy of life, the conatus reason is not at all enough for man to feel himself as the end of existence. And, in fact, only this feeling supports dignity. If man cannot manifest his creativeness and see that the others do not consider his possibility and humanity, he does not feel dignified, but reduced, insignificant.

The above-mentioned ontological concepts show that dignity and the claim to be dignified are not absurd and artificial, "culturally made" qualities. They certainly are culturally forged, but not this aspect was emphasised here: but the fact that the feeling to be dignified corresponds to the deep resorts of the human being. If man enjoys his life not as pleasure, but as creation - he is available to fight for life and to cherish life. And if he fights for life, it does this not as a simple animal creature, but from the standpoint of a conscious being: conscious about his uniqueness and worth despite his finite and limited existence.
But there is the mutual causality we understand. To the consciousness, joy of life and determination to fight for life contributes the state of dignity: i.e. the state given by the others, by society. The human ontology cannot explain man and the individual existence on the basis of methodological individualism. From the beginning, man is a relational concept, and the conclusion of the reason of conatus and joy of life is that: since the individual wants to actualise his potentiality, to fulfil - and he wants in a rational manner, by proposing to himself only those goals possible according to his potentiality $^{7}-$, and he cannot do this with all his effort, and in this situation he does no longer have motivations to live and life is no more beautiful for him, society and its brakes need to be discussed.

And if society does not consider that the individual's aim to fulfil is organic, therefore if society does not endorse this aspiration, the dignity of everyone and all could be annulled. The historical and social mediation and reality in the human ontology is thus sine qua non.

\footnotetext{
${ }^{7}$ Letting here aside the social conditions and the ideologies which legitimise the human aspirations and the power of action only according to the social place people occupy, in this manner circumscribing even the potentialities of every person, normal people do not want what they are not interested in / what they cannot do with their own power. If I have no musical voice, I want not be an opera singer.
}

But at the same time, people are frustrated if they cannot - because of the social conditions - do and become what they could through their own power, and the philosophers (Aristotle, Leibniz) have shown that freedom is just the situation when people do what they rationally want with their own powers. See (Bazac 2015b). For his reason, one cannot speak about freedom in the case of those subjected, constrained by their social condition, even though they accept the relations arising from this condition; there is no such thing as "consensus" in structurally asymmetric relationships between those who have the means to impose these relationships and those who have not. 
Both the concepts of its ontological basis and dignity as such are criteria for the analysis of the human being and society.

Indeed, although the will and choice exercised in order to attain self-esteem and self-realization belong to the individual, they reflect the social and historical circumstances where the consideration of the others is crucial.

If this consideration is missing and if the lack of human conditions and future substitutes the opportunities, people are far from the situation to demonstrate their human dignity. And if they are not dignified, if the others do no longer consider them as worthy of representing the human dignity, they become indignant towards this condition: in Latin, in + dignatio means just the opposite situation to dignity, and the awareness of the situation where the others do no longer treat a person with respect for his/her humanity, but treat him/her indigne - unjustly, with cruelty, shamefully.

Therefore, indignation - and we are facing nowadays waves of worldwide indignation against the disregard of the right to be considered, each of us, as a unique and unrepeatable human person - is the natural, but human answer to undignified behaviour towards us. Indignation belongs to the human person, not to the abstract man. But, just because the worth of the human person is jolted, the worth of man as such is jolted (see Bazac 2015a).

Our questions, expectations and aspirations, our indignation in front of the lack of dignity of those who do not behave unworthy are answered to if we do not separate the illusive ontology of the individual - a historical construction of the European philosophy constraint by the dominationsubmission frame - from the societal analysis.
Therefore, although the concept of dignity can be analysed starting from the human conatus which is an individual faculty or force -, it is incomprehensible without connect it to, or more, without integrating it within the social complex. First of all, the individual translation of the human conatus in the concept of dignity/as dignity already supposes the social character of man. The instruments of the individual, necessary for his survival, are social. The language through which he expresses his self-consciousness as his own dignity is social. The nuances his self-consciousness realises as feelings and their expressions are borrowed from the culture known by the individual.

But leaving this aside, and considering as a beginning of the analysis the individual feeling of dignity as the transposition of his will to live, this feeling is vague, ineffable and evanescent if it would not have the positive or negative reactions of society towards it. Indeed, society is the ultimate criterion of the individual consciousness of dignity, because it accredits this individual feeling. If, by absurd, there would not exist society - or the individual would live in an individual niche and would not know anything about society (but, for the sake of our philosophical experiment, he could express through meaningful words his feelings) - the individual would not be sure that he has a constitutive dignity and he deserves dignity. Only the others authorise this feeling, whether they endorse it or not, having the function of a thermometer measuring the individual belief.

And if society refuses this individual belief, even this one shatters and vanishes: "may be I am a bad egg, a nobody; I do not deserve the others' consideration of my existence and unique possibility". And since this existence is not considered by society, the individual too can no longer cherish it: the original conatus - that which differentiates between the animated and inanimate things - disappears, and the life of the individual is derived from 
any value for him; because: it lost any value for society.

By explaining the intertwining of society and the individual in both the historical constitution of the concept of dignity and the realm of human ontology, we suddenly shudder in front of the real social relations and become more responsible towards the social appellations attributed to people. We certainly know that these appellations were constituted in the frame of power relations, but now we are more careful concerning names, communication, labels, since they can shape the thinking and life of so many individuals. I speak here only about theoretical care, and this one concerns first of all the consistency of our reasoning and theories. Yes, on the one hand, we raise hosannas to the concept of dignity and see it as related to every individual. But on the other hand, we do not inquire - and anyhow not all the way (and this last expression means to epistemologically and critically support all kinds of studies concerning the meanings and consequences of theories and ideological messages; an absolutely necessary support (see Bazac 2013)) - the results of the social relations and denominations promoted by the ideological mainstream over the individual consciousness.

And these results are disastrous: if an individual is systematically called a rag - but this means treated as a rag -, his consciousness of his dignity is jolted and he will no longer cherish his genuine dignity, but will behave as a ragamuffin, a punk, a good-for-nothing. Neither his dignity nor the others' exist for him anymore. He has no longer human aspirations - and to preserve his own dignity is no longer an aspiration - and refuses to consider the human aspirations of the others.

Actually, the cause of the contradistinction highlighted above is the abstract individualism specific to the mainstream theories having the methodological individualism as a background. In their abstract representation of the individual, this one has a theoretical charisma that sends to the presupposition of the exceptional character of the indi- vidual taken into account. And, obviously, this exceptional character seems to exclude the concrete individuals from the masses. Namely, this theoretical pattern opposes the glorified but abstract individual to the grey masses. However, the result is not the understanding of the individual, since this one is not concrete, i.e. whichever and everyone and, at the same time, unique. Rather the opposite pattern - let say, methodological collectivism - is fruitful.

In this pattern, no individual is covered by the mass/collective/community it belongs to, and not the mass/collective/community is the first factor of the explanation, but the couple individual-mass. Therefore, the methodological collectivism is not the pendant of the methodological individualism, bearing the same dogmatic bias but with a contrary sign. Thus, the mass is not grey at all - i.e. it has not only the characteristics of a collective system - but is constituted of unique individuals, every one of them with its own standpoint, soil and anchor.

This mass was called by Spinoza multitudo. It was not a disciplined entity, having $a b$ initio one will and behaving as One person. On the contrary, its constitution was the result of fierce debates, and the common goals and means were always revisable according to the individual interests and standpoints. In Spinoza, "the multitudo indicates a plurality which persists as such in the public scene, in collective action, in the handling of communal affairs, without converging into a One, without evaporating within a centripetal form of motion. Multitude is the form of social and political existence for the many, seen as being many: a permanent form, not an episodic or interstitial form. For Spinoza, the multitudo is the architrave of civil liberties" (Virno 2004: 21).

If so, in the type of society constituted from and developing this multitudo, dignity still remains the cherished good of the individual, it does not transcend this one and does not become only the specific of an abstract community or institution. Consequently, in order to preserve the individual 
dignity of every one and all, we need to surpass the pattern which refuses the concreteness of whichever from the inherent mass ${ }^{8}$.

\section{Uncomfortable question}

If the manner to be of dignity - or its ontological character - is a basic presumption, how is it substituted with the presumption of selective dignity? I do not discuss here the violation of the expectations of being to be considered dignified, since this violation is the result of domination-submission relations, but the legitimating of or the refusal to question the selective dignity: so, the ideas or representations of this phenomenon. These ideas are dominant in the social organisation based on domination-submission relations and are promoted by the intellectuals.

The representation of the selective dignity illustrates the real face of the Western intellectuals as it was grasped even by one of them, a "classicist" but not a naïve idealist. Julien Benda has emphasised the betrayal of the intellectuals (Benda 2006) as abandonment of the universalistic values and rationalist criticism and as taking over and supporting of the particularistic values and standpoint. But just through this turn man is no longer considered as a being unconditionally deserving dignity: "our culture/civilisation", "our people", "our religion", "our group/clan/family" are the viewpoints fragmenting not only humankind, but also the approach/logic of human identity. Because: "ours" has in subtext not the simple concrete manifestation of the values and forms of mankind, and the joy occasioned by experiencing them, but the opposition in a way or another to all other "ours".

The particularistic approach promoted by so many leading intellectuals in the First World War ${ }^{9}$

\footnotetext{
${ }^{8}$ The theory of mutuality opposes the abstract theory of dignity. According to (Bowles and GINTIS 2011), just mutuality has generated human persistence, development and dignity at a progressively larger scale.
}

and experienced by Benda has led to the known tragedies of colonialism (before and after the First World war, of course), of Nazism, militarism, of attacks on independent countries, of destruction and the consideration of the civil casualties as "collateral damages" (see an analysis of the wars by deputy through the focus on one of the most significant technical means mediating the warrior relations of the attacker and the attacked - Chamayou 2013): this particularistic approach was and is not at all interested about the dignity of the others outside the imagined circle of the close-knit. On the contrary, these others are only a means, an object on which the powerful exert their power, and their arbitrary interest - without taking into account the reasonable will of the attacked, which they annul they may kill cohorts of people without any punishment. The powerful think they have impunity ${ }^{10}$. But if they have this power, they should expect at the same attitude from the others, should they?

This correspondence is obvious not only in the exceptional relations concerning individual killings and mass slaughters, but also in the "normal" situations when, despite the huge progress of civilisa-

${ }^{9}$ I began to read something about this problem when I worked at the paper (Bazac 2005) and I confronted Einstein's social non-conformism to the dominant intellectual conformism which led to the signature by 93 German intellectuals of a pro-war manifesto in 1914. Einstein and only 3 other scientists have signed a counter-manifesto, pro peace.

See also: Nees 2014.

${ }^{10}$ Impunity is immunity. But what does immunity means? According to (Esposito 2011: 5, 6), "munus refers to an office - a task, obligation, duty (also in the sense of a gift to be repaid), by contrast, immunis refers to someone who performs no office... Whoever is disencumbered, exonerated, exempted (dispensatio) from the pensum of paying tributes or performing services for others, is defined as immune. Those who are immune owe nothing to anyone, in terms of both vacatio and excusatio; ..."but it is also a privilege. Immunity is perceived as such when it occurs as an exception to a rule that everybody else must follow". 
tion, some categories of people - who are not the usual subjects of particular discrimination (as the present immigrants) - seem to have been "destined to be dead", internalising the "sentiment of not being really welcomed" and thus being "'infinitely more fragile, brutish, sad, pallid, and ill than all preceding generations'", marked by "'the shadow that an unknown abnormality projects over their life'”. This is, as Pasolini has formulated, an "'anthropological mutation'” (Escobar 2014).

Only as example, as illustration of the universalist values, or clearer, only integrated within universalism is particularism an acceptable ideology.

Passing over the (including pre-modern) history of the idea of dignity in relation with the intellectuals, the hypothesis of the present work is that the attitude of the intellectuals towards the problem of dignity or lack of dignity has followed the evolution of modernity: concretely, the sociological status, the appurtenance of the intellectuals to the "middle classes". As a result, the intellectuals have spoken in the name of these classes - ultimately, only in the name of the dominant class and much rarer from the standpoint of the ruled classes.

The societal crisis of capitalism

As all the social-economic systems, capitalism has an evolution figured through the form of a bell or pointed arch. In a very brief presentation, while at the beginning the new productive relations have stimulated the development of the productive forces, from a moment on, the advancement generated by the development of these productive forces is more and more countered by the same productive relations and the negative phenomena resulted from these ones. This moment begins the system crisis. And although capitalism enters - say, from the 70s of the last century on - its trans-national phase that fortifies $i t^{11}$, just despite of this strengthening of capital does the crisis show itself ${ }^{12}$. Actual-

${ }^{11}$ Through delocalization, the capital owners dispose of the labour force of the whole world, thus of cheaper labour force than that of the traditional countries where these capital owners reside. They sell the products of this world labour force everywhere and, by using the wage earners (with tiny wages) from the "emergent" countries, they can however sell (at least some of) their products even in these countries. But not the international trade is the mark of transnationalization of capital (from this point of view, there were globalised periods of capitalism much earlier than the present one), nor the export of capital and the seizure of resources and the subjugation of the peoples through political means: but just the relationship of capital with the labour force and with the states. This relationship integrates the whole world labour force into the logic of the more powerful capital and puts the states into a savage race of competition in order to "attract" the trans-national capital. In this frame, the labour force is no longer defended by the states, as in the post-war period of welfare state. Transnationalisation means also financialisation, i.e. the autonomy of the financial capital towards states but also towards the productive capital: but this autonomy means concentration of power, superiority in the logic of capital. The reason of this phenomenon was and is the huge world competition and the fall of the rate of profit in the productive realm because of the rapid generalization of new technologies with all its aspects.

But all these phenomena led, on the one hand, to the strengthening of capital, i.e. of the financial capital (which has more money to buy the resources and the means of existence of the world and, obviously, to pay the ideologists and mass media). This enrichment means a never seen social polarisation, supporting the metaphor of the $1 \%$ versus $99 \%$. (Actually, this is not only a metaphor).

On the other hand, even the world economic and political competition and the present scientifictechnological revolution, together with the giant world problems and contradictions and the social consciousness of the many, lead to the weakening of capital.

12 There is a general crisis of institutions, an "omnicrisis" (Hardt and Negri 2001: 189, 197). 
ly, capitalism has no longer solutions for the global problems it has created and which agglomerate and not alleviate at all.

Anxiety of the intellectuals

In this period, because the scientific and technological revolution generates a convergence of the physical and intellectual labour, on the basis of the weakening of the social division of labour, namely on the basis of the loss by the intellectuals of their traditional "exceptional" social place, as well as on the basis of the gradual loss of the advantages of the middle classes gained during the post-war welfare state, the intellectuals become more preoccupied with phenomena and concepts related to their own worldly life.

The present world economic crisis that is not finishing (Beams 2012) hits the intellectuals too. They still do have a cognitive capital that they hope to sell in the most advantageous manner possible. They still have the inertia of the intermediary bureaucratic category they belong to, and thus, the illusions of this category.

It is about an ideological illusion: concerning both their exceptional status - as if no change would have occurred at the level of general cognisance, communication and labour - and the possibility of a real dignity of everyone in the frame of capitalist relations. Or, this last aspect is substituted with the total exclusion of the problem of dignity of all from their consciousness.

The sociological explanation of the attraction of the intellectuals - and I think there is no much difference between the scientific ones and those from humanities - for some concepts and topics aims at emphasising some epistemological aspects of the approach of the concept of dignity. One example is the predilection of the mainstream intellectuals for the political rights in the frame of the Western type representative democracy, which, however, do not lead to the human dignity of all.
Instead of conclusions

But dignity is a metaphysical concept: a basis of the efficient concepts - if I may transpose Aristotle's theory of the four causes - or concepts-means (as the rights).

There is a balance between the universal and the particular of this concept. This balance takes into account both the dignity of the individual and of the institution/community/people/culture.

Both the substantive/essentialist and the relational concepts of dignity may be interpreted in a more efficient manner through the sociological lens.

The European philosophers have focused on rather indirectly, through the concepts of liberty and responsibility, for example - the dignityaspiration: as an implicit, though vague and mostly unconscious critique of society.

They have focused on the dignity of the $a b$ stract individual - which they tried to represent in the best manner, and which, rather unconsciously, superposed their own figure/the figure of the intellectual - because they had no instruments to go to the concrete and whichever one.

Nowadays - in a full and visible system crisis there still are some intellectuals who think that dignity would be hit only by the economic crisis.

The more the system crisis advances, the more some intellectuals think that dignity would be imposed - if they think about dignity at all - through the restoration of some out-of-date relations, as those of the welfare state, and values, as those of the "national capital". But these ones do not represent the universal. On the contrary, and even though the illusion of the possibility of their restoration could pertain also to countries fighting the terrible unipolar "Empire" of the Western imperialism, in fact they prolong the domination-submission relations. Letting aside that the above-mentioned fight is inherent/objective, it is necessary. But the particularistic consciousness of the intellectuals - is not. 
Some intellectuals see the jolted dignity of the "middle classes" and intellectuals through the old abstract lens: and wonder why this dignity is so weak.

But, by thinking in this manner, they contribute, consciously or unconsciously, to the preser-

\section{REFERENCES}

Augustin, Saint. (1855). La cité de Dieu (426) (Traduction nouvelle avec une introduction et des notes par Émile Saisset). Paris: Charpentier Libraire-éditeur.

Bergson, H. (1919). "L'énergie spirituelle» (1911). n Essais et conférences. Paris: Félix Alcan.

Bazac, A. (2005). "Umanism aplicat: libertatea umană şi perspectivele ei la Albert Einstein". Revista de Filosofie, 5-6, pp. 703721 (Applied humanism: freedom and its perspectives in Albert Einstein).

Bazac, A. (2013). pp. 145-157. "Global injustice: what is known, what is assumed and what is promised?". Studia UBB, Philosophia, 58 , No.2.

Bazac, A. (2015a). pp. 104-115. "Person - for Me, and Object - for the Other? How Does Humanism Occur?" Dialogue and Universalism, Vol. XXV, No. 2.

Bazac, A. (2015b)."L'échelle mineure et l'échelle majeure de l'impossible", Analele Universității din Craiova. Seria Filosofie. Nr. 35 (1), pp. 167-188.

Beams, N. (2012). "Downturn to continue for a generation, Bank of England governor warns". 24 October, http://www.wsws.org/articles/2012/oct 2012/king-o24.shtml

Benda, J. (2006). The Treason of the Intellectuals (1927). (Translated by Richard Aldington (1928), Introduction by Roger Kimball). New Brunswick (U.S.A.) and London (U.K.): Transaction Publishers. vation of the pattern of social relations linked only to a selective dignity. In fact, they do not leave room - nor time; actually, they waste the time necessary to humankind - for the research of the possibility of the dignity of every one and all.

Bowles, S., Gintis, H. (2011). A Cooperative Species: Human Reciprocity and Its Evolution. Princeton: Princeton University Press.

Burkhardt, J. (1978). The civilization of the Renaissance in Italy (1860). Translated by S. G.C.Iddlemore, Viena: The Phaidon Press; New York: Oxford University Press.

Camus, A. (1942). Le mythe de Sisyphe. Essai sur l'absurde (1942). Édition augmentée (69ème). Paris: Gallimard.

Chamayou, G. (2013). Theorie du drone. Paris: La fabrique.

Descartes, R. (2000). Discourse on Method (1637), in Discourse on Method and Related Writings, Translated by Desmond M. Clarke (1999). London: Penguin Books (Penguin Classics).

Diogenes, L. (1972). Lives of the Eminent Philosophers. (Translated by Robert Drew Hicks (1925), Harvard University Press.

Erasmus of Rotterdam, (1524). De libero arbitrio diatribe sive collatio, https://magiste rvenemus.wordpress.com/erasmus-de-liberoarbitrio/

Escobar, P. (2014). We are all living Pasolini's Theorem, January 17. http://www.atimes.com/atimes/World/WOR-02170114.html (Accessed January 18, 2014).

Esposito R. (2011). Immunitas: The Protection and Negation of Life. (2002). London: Polity.

Hardt, M. and Negri, A. (2001). Empire (2000). Cambridge, Ma.; London: Harvard University Press.

Kant, I. (1996). "Answer to the Question: What is Enlightenment?" (1784), in Practical Philosophy. Translated and edited by Mary J. 
Gregor (The Cambridge Edition of the Works of Immanuel Kant). Cambridge: Cambridge University Press.

Leibniz. (1921). Nouveaux essais sur l'entendement humain (1704/1765). Paris: Ernest Flammarion.

Leibniz, G.W. (1890). "On the Reform of Metaphysics and of the Notion of Substance" (1694). In The Philosophical Works of Leibniz. Translated from the original Latin and French, with notes of George Martin Duncan. New Haven: Tuttle, Morehouse \& Taylor Publishers.

Leibniz, G. (1890). The Monadology (1714). In The Philosophical Works of Leibniz. Translated from the original Latin and French, with notes of George Martin Duncan. New Haven: Tuttle, Morehouse \& Taylor Publishers.

Martin, W. (2006). Stoic Self-Consciousness: SelfComprehension and Orientation in the Stoic Theory of Oikeiosis. http://privateww

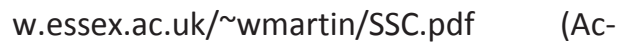
cessed August 12, 2015).

Pico, G. della Mirandola (1996). Oration on the Dignity of Man (1486). Translated by A. Robert Gaponigri, Introduction by Russell Kirk. Chicago: Gateway Editions, Reprint edition.
Nees, V. (2014). German intellectuals in World War

I. 20 October, http://www.ws ws.org/en/articles/2014/10/20/germ-o20. Html.

Platon. MDCCCXL. «Définitions». In Oeuvre de Platon, Tome XIII, Traduites par Victor Cousin. Paris: P-J Rey Libraire.

Spinoza, B. (2002). Ethics (1677), in Complete Works. With Translations by Samuel Shirley, Edited, with Introductions and Notes, by Michael L. Morgan. Indianapolis/Cambridge: Hackett Publishing Company.

Aquinas, Th. (1265-1274). Summa Theologica. Secunda Secundæ Partis, Question 64. Murder, Article 5. Whether it is lawful to kill oneself?, Article 1, Reply to Objection 1, http://www.newadvent.org/summa/3064. htm And Article 5, http://www.newadvent.org/ summa/3064.htm\# article5

Virno, P. (2004). A Grammar of the Multitude: For an Analysis of Contemporary Forms of Life (2003). Translated by Isabella Bertoletti, James Cascaito, Andrea Casson. Los Angeles, New York: Semiotext(e)/ Foreign Agents. 